\title{
Association Between Local Government Social Expenditures and Mortality Levels in Korea
}

\author{
Hansoo Ko, Jinseob Kim, Donggil Kim, Saerom Kim, Yukyung Park, Chang-yup Kim \\ Preventive Medicine Program, Graduate School of Public Health, Seoul National University, Seoul, Korea
}

Objectives: We examined the association between social expenditures of the local government and the mortality level in Korea, 2004 to 2010 .

Methods: We used social expenditure data of 230 local governments during 2004 to 2010 from the Social Expenditure Database prepared by the Korean Institute for Health and Social Affairs. Fixed effect panel data regression analysis was adopted to look for associations between social expenditures and age-standardized mortality and the premature death index.

Results: Social expenditures of local governments per capita was not significantly associated with standardized mortality but was associated with the premature death index (decline of 1.0 [for males] and 0.5 [for females] for each expenditure of 100000 Korean won, i.e., approximately 100 US dollar). As an index of the voluntary effort of local governments, the self-managed project ratio was associated with a decline in the standardized mortality in females (decline of 0.4 for each increase of $1 \%$ ). The share of health care was not significant.

Conclusions: There were associations between social expenditures of the local government and the mortality level in Korea. In particular, social expenditures per capita were significantly associated with a decline in premature death. However, the voluntary efforts of local governments were not significantly related to the decline in premature death.

Key words: Social expenditure, Local government, Mortality,

\section{INTRODUCTION}

Health status is affected by social determinants. Furthermore, it is known that not only individual traits, but social, economic, educational, and cultural factors at a local level affect health status. 'Local' is not only the area of residence but

Received: June 28, 2012 Accepted: October 12, 2012

Corresponding author: Chang-yup Kim, MD, PhD

1 Gwanak-ro, Gwanak-gu, Seoul 151-742, Korea

Tel: +82-2-880-2722, Fax: +82-2-762-9105

E-mail: cykim@snu.ac.kr

This is an Open Access article distributed under the terms of the Creative Commons Attribution Non-Commercial License (http://creativecommons.org/licenses/bync/3.0/) which permits unrestricted non-commercial use, distribution, and reproduction in any medium, provided the original work is properly cited. also a determinant for health in that it limits the living environment. Furthermore, in addition to these meanings of 'local', the local government is a basic administrative unit for actualization and practical realization of local issues and demands. For this reason, domestic studies on the differences in health status among local areas and the main causes of these differences have been performed [1-4].

The policies and expenditures of the local government affect local residents in a narrow sense, in that projects are customized in each area according to the residents' demands and in a broad sense through city planning and attracting enterprises. In particular, in Korea, it should be noted that the contexts of policies and expenditures among local governments have diverged since local government leadership positions 
became elected positions in 1995. In addition, recent increases in social expenditures should be considered as well; the average annual increase has been $16.8 \%$ from 1990 to 2003 [5]. At this point, the question can be raised about how policies and expenditures of local government practically affect residents. More specifically, the question of whether social expenditures of local governments have a positive effect on the residents' standard of living and their welfare is worth asking.

The purpose of this study is to investigate the association between the social expenditures of local governments and the collective health status at the local level. Health status is considered to be a performance indicator through social expenditures; however, so far, local governments have focused on analyzing determinants of social expenditures [6-8]. The history of local government in Korea is relatively short, and the collection of data has been insufficient. Besides, the macroscopic perspective on the factors affecting health status has not been clearly developed.

So far, no domestic study has directly examined the relationship between the social expenditures of local governments and the health status at the local level. According to a previous study on the association between public social expenditures and suicide in 27 Organization for Economic Cooperation and Development countries, an annual increase in social welfare expenditures was related to a decrease of the suicide rate. However, the difference between that study and the present study is that health status in the previous study was measured only by suicide rates, and it was comparative study among nations instead of domestic local areas [9]. In another Korean study analyzing factors affecting the suicide rate in 248 cities, counties, and provinces from 2006 to 2008, no significant relationship was found between the proportion of two local government expenditures spend on social welfare and the suicide rate [10].

Meanwhile, a number of studies on the effect of public social expenditures of local governments on the suicides rates as an indicator of health status have been published in other countries [11-15]. In Rajkumar and Swaroop's study [11], the relationship between the public social expenditures relative to the gross domestic product and the under- 5 mortality rate with ordinary least square regression analysis combining data from three years in 91 countries was reported; however, that study analyzed multiple countries, sub-items of the social welfare expenditures were not included, and the range of dependent variables was insufficient. Among several studies on the effect of the public expenditure of local governments on health status, the study of Dunn et al. [12] had the limitation of a cross-sectional approach using data in only a certain year. Kim and Jennings' study [13] using panel data also had a limitation, in that the standardized mortality rate was the only dependent variable. In addition, in this study, the relationship between the actual public expenditure and the standardized mortality rate was not identified. The study of Farahani et al. [14] is different from the present study in terms of the multilevel analysis, in that variables related to the local government level were included in the data of the private level. Minoiu and Andres [15] reported that the percentages of public health and welfare expenditures out of the total expenditures in every state of the United States were related to the decrease in the suicide rates from 1982 to 1997. However, like other studies, explanatory variables and dependent variables were insufficient and not concrete.

Referring to previous studies, the social expenditures per capita and variables like social welfare, health care, and educational welfare, which are the functional substructures in the social expenditure database were included in this study. Moreover, to investigate the effect of the social expenditures of local governments on their (local) mortality levels, the age-standardized mortality rate and the premature death index were treated as dependent variables. Furthermore, using panel data, the dynamic relationship by repetitive observations was estimated and the statistical stability was acquired [16]. Hypotheses of this study are as follows: 1) There should be an association between the social expenditures of local governments and the age-standardized mortality rate as a local collective mortality level. 2) If the social expenditures affect the age-standardized mortality rate, the reason for it should be that social expenditures can cause a decrease in the incidence of premature death, a proxy for social loss. 3) In terms of the voluntary efforts of local governments to provide for the social welfare, a high percentage of self-operated social welfare projects and financial coverage (the local government's own social expenditures) for local social welfare would have positive effects on local mortality rates.

\section{METHODS}

Geographic areas were classified into cities, counties, and provinces according to the government administrative system. For the data on the social expenditures by cities, counties, and provinces, the raw data from the Social Expenditure Database 
(DB) provided by the Korean Institute for Health and Social Affairs (KIHASA) from 2004 to 2010 was used. Data for total expenditures, the local tax, the self-reliance ratio of local finance, and the number of beneficiaries for National Basic Living Security were variables provided from KIHASA. In addition, the number of resident registrations, the divorce rate, and the age-standardized mortality rate out of the total population in 2005 were collected from the data of Statistics Korea.

The raw data of the Social Expenditure DB is panel data established in 230 cities, counties, and provinces (228 cities, counties, and provinces in 2010 because the city of Masan and Jinhae were integrated into the city of Changwon in South Gyeongsang Province [Gyeoungsangnam-do] in 2010) from 2004 to 2010. The panel regression model, which contained the age-standardized mortality rate by sex in cities, counties, and provinces from 2005 to 2010 as a dependent variable, was used to analyze the effect of the social expenditures on the mortality level. Explanatory variables by the classification of functional structure in the Social Expenditure DB are as follows: the total social expenditures per capita, the health care expenditures, the expenditures for food and drug safety, and the sum of social welfare expenditures per capita for National Basic Living Security, the support for vulnerable social groups, child care, families, women, seniors, adolescents, labor, veterans, and housing, the expenditures for educational welfare for preschool, elementary, middle, and high school education, and continuing and occupational education. In addition, the share of social expenditures, the share of health care expenditures, and the share of food and drug safety expenditures out of the total expenditures were calculated.

Next, the regression model for the premature death index as a dependent variable was used to examine the effect of social expenditures on the decrease in premature death. This premature death is socially disadvantageous. The premature death index represents the years of potential life loss, which means the sum of premature death years in those who died at age 75 years old and below are calculated per 1000 people $[4,17]$.

A lag effect of one to two years was also shown because the effect of the social expenditures on health status would not appear immediately. In a previous study analyzing 25 years of data, a one-year lag effect was adopted [15]. In this study, the reason a one- to two-year lag effect was applied was to minimize the decrease in the sample size in the regression model, because data for the dependent variables were from 2004 or 2005 to 2010. Another reason is that the interpretation of the results would be difficult in case of the applying a longer lag effect because the election cycle for the local governments of Korea is four or five years, and social welfare policy can change after an election.

The response and the effort of local governments to address local health issues and social welfare demands are the main factors guaranteeing the effectiveness and the efficiency of their projects. However, it is difficult to characterize large social expenditures of local governments to mean the active response to social welfare demands because some portion of the social expenditures of local governments is supported by the central government.

According to a previous study, the proportion of social welfare projects that a local government operates and funds itself is a better indicator of their voluntary effort than the proportion of the budget spent on social expenditures or the amount of social expenditures per capita. The proportion of the local government's budget dedicated to locally managed social welfare projects (the social expenditures of the locally managed projects/the total social expenditure $\times 100$ ) and the share of the local government's budget allocated to self-financed social expenditures (the share of social expenditures financed by the local government/the total social expenditure $\times 100$ ) as variables show the local government's voluntary effort on local health issues and their demands [18]. In this model, the result taking into account the lag effect was not shown because the data for locally managed and funded social welfare projects were collected only from 2007 to 2010.

The fixed effect model was used in the panel regression model to reflect the unique characteristics of each of the 230 cities, counties, and provinces. Because factors affecting the local mortality rate are diverse, adjusted variables included years, local tax rates per capita, the number of National Basic Living Security beneficiaries per 1000 people, the divorce rate, and a local dummy variable (urban/rural). Akaike's information criterion was used to select adjusted variables. The autocorrelation was verified by a Wooldridge test in every regression model. Statistical analysis was performed with STATA version 12 (Stata Co., College Station, TX, USA).

\section{RESULTS}

The general statistics for major variables by city, county, and province from 2004 to 2010 are shown in Table 1. As the years passed, social expenditures have increased, while male and fe- 
Table 1. General characteristics of regions in Korea, 2004 to 2010

\begin{tabular}{|c|c|c|c|c|c|c|c|}
\hline & 2004 & 2005 & 2006 & 2007 & 2008 & 2009 & 2010 \\
\hline Total expenditures & $\begin{array}{c}282000 \\
(213000)\end{array}$ & $\begin{array}{c}309000 \\
(229000)\end{array}$ & $\begin{array}{c}337000 \\
(267000)\end{array}$ & $\begin{array}{c}363000 \\
(296000)\end{array}$ & $\begin{array}{c}420000 \\
(295000)\end{array}$ & $\begin{array}{c}445000 \\
(312000)\end{array}$ & $\begin{array}{c}429000 \\
(305000)\end{array}$ \\
\hline Total social expenditures ${ }^{1}$ & $\begin{array}{c}44400 \\
(27500)\end{array}$ & $\begin{array}{c}54600 \\
(33600)\end{array}$ & $\begin{array}{c}63300 \\
(40300)\end{array}$ & $\begin{array}{c}71600 \\
(75000)\end{array}$ & $\begin{array}{c}86600 \\
(53000)\end{array}$ & $\begin{array}{c}106000 \\
(67200)\end{array}$ & $\begin{array}{l}115000 \\
(80000)\end{array}$ \\
\hline National basic livelihood security & $\begin{array}{r}13000 \\
(8632)\end{array}$ & $\begin{array}{c}14800 \\
(10100)\end{array}$ & $\begin{array}{c}16200 \\
(11300)\end{array}$ & $\begin{array}{c}20000 \\
(13300)\end{array}$ & $\begin{array}{c}21600 \\
(14300)\end{array}$ & $\begin{array}{c}24800 \\
(16700)\end{array}$ & $\begin{array}{c}23200 \\
(16900)\end{array}$ \\
\hline The disadvantaged group & $\begin{array}{c}2121 \\
(2131)\end{array}$ & $\begin{array}{c}2935 \\
(4212)\end{array}$ & $\begin{array}{c}3330 \\
(2906)\end{array}$ & $\begin{array}{c}9480 \\
(6936)\end{array}$ & $\begin{array}{c}10700 \\
(7555)\end{array}$ & $\begin{array}{r}12500 \\
(9047)\end{array}$ & $\begin{array}{c}13800 \\
(11100)\end{array}$ \\
\hline Senior & $\begin{array}{c}7422 \\
(5044)\end{array}$ & $\begin{array}{c}7994 \\
(4412)\end{array}$ & $\begin{array}{c}10400 \\
(6068)\end{array}$ & $\begin{array}{r}12200 \\
(6732)\end{array}$ & $\begin{array}{c}20600 \\
(10900)\end{array}$ & $\begin{array}{c}24600 \\
(12800)\end{array}$ & $\begin{array}{c}25500 \\
(14700)\end{array}$ \\
\hline Health care & $\begin{array}{c}5684 \\
(6207)\end{array}$ & $\begin{array}{c}6638 \\
(5678)\end{array}$ & $\begin{array}{c}7045 \\
(4356)\end{array}$ & $\begin{array}{c}6720 \\
(4012)\end{array}$ & $\begin{array}{c}7485 \\
(4648)\end{array}$ & $\begin{array}{c}7807 \\
(4553)\end{array}$ & $\begin{array}{c}8027 \\
(4981)\end{array}$ \\
\hline Food and drug safety & $\begin{array}{l}70.3 \\
(22)\end{array}$ & $\begin{array}{c}67.3 \\
(26)\end{array}$ & $\begin{array}{c}55.8 \\
(20.4)\end{array}$ & $\begin{array}{l}699 \\
(55.9)\end{array}$ & $\begin{array}{c}400.4 \\
(573.7)\end{array}$ & $\begin{array}{c}485.4 \\
(422.8)\end{array}$ & $\begin{array}{r}534.2 \\
(453.3)\end{array}$ \\
\hline $\begin{array}{l}\text { National basic livelihood security } \\
\text { recipients }(n)\end{array}$ & $\begin{array}{c}6009.2 \\
(4093.5)\end{array}$ & $\begin{array}{c}6420 \\
(4455.5)\end{array}$ & $\begin{array}{c}6525.9 \\
(4640.8)\end{array}$ & $\begin{array}{c}6593.3 \\
(4732.1)\end{array}$ & $\begin{array}{c}6530.9 \\
(4772.2)\end{array}$ & $\begin{array}{c}6686.2 \\
(4997.5)\end{array}$ & $\begin{array}{r}6705.2 \\
(5159.4)\end{array}$ \\
\hline Populations (n) & $\begin{array}{c}208819.3 \\
(191312.4)\end{array}$ & $\begin{array}{c}209672.6 \\
(193476.7)\end{array}$ & $\begin{array}{r}210579.5 \\
(195609.2)\end{array}$ & $\begin{array}{c}211781.2 \\
(197181.5)\end{array}$ & $\begin{array}{l}212955.4 \\
(198866)\end{array}$ & $\begin{array}{c}213958.6 \\
(200354.1)\end{array}$ & $\begin{array}{c}219054.4 \\
(211127.7)\end{array}$ \\
\hline Local tax revenue $^{1}$ & $\begin{array}{c}39900 \\
(54100)\end{array}$ & $\begin{array}{l}42800 \\
(60200)\end{array}$ & $\begin{array}{c}47400 \\
(67200)\end{array}$ & $\begin{array}{c}54600 \\
(78500)\end{array}$ & $\begin{array}{c}61300 \\
(86700)\end{array}$ & $\begin{array}{c}63800 \\
(86700)\end{array}$ & $\begin{array}{c}66500 \\
(64900)\end{array}$ \\
\hline Financial independence ratio (\%) & $\begin{array}{c}29.7 \\
(16.5)\end{array}$ & $\begin{array}{c}30.4 \\
(17.6)\end{array}$ & $\begin{array}{l}28.9 \\
(17)\end{array}$ & $\begin{array}{l}28 \\
(16.3)\end{array}$ & $\begin{array}{c}28.3 \\
(16.9)\end{array}$ & $\begin{array}{c}28.7 \\
(17.1)\end{array}$ & $\begin{array}{r}28.2 \\
(16.6)\end{array}$ \\
\hline Standardized mortality (M) $)^{2}$ & - & $\begin{array}{c}741.5 \\
(100.2)\end{array}$ & $\begin{array}{l}708.7 \\
(97)\end{array}$ & $\begin{array}{l}680.4 \\
(91.1)\end{array}$ & $\begin{array}{l}662 \\
(90.9)\end{array}$ & $\begin{array}{l}634 \\
(89.5)\end{array}$ & $\begin{array}{l}626 \\
(88.1)\end{array}$ \\
\hline Standardized mortality $(F)^{2}$ & - & $\begin{array}{l}376 \\
(41.7)\end{array}$ & $\begin{array}{c}355.8 \\
(38.7)\end{array}$ & $\begin{array}{c}344.9 \\
(38.5)\end{array}$ & $\begin{array}{l}324 \\
(35.4)\end{array}$ & $\begin{array}{c}308.9 \\
(35)\end{array}$ & $\begin{array}{c}302.2 \\
(32)\end{array}$ \\
\hline Premature death index (M) & $\begin{array}{c}92.8 \\
(28.1)\end{array}$ & $\begin{array}{c}87.1 \\
(25.8)\end{array}$ & $\begin{array}{c}83.4 \\
(25.3)\end{array}$ & $\begin{array}{c}80.8 \\
(23.4)\end{array}$ & $\begin{array}{c}79.3 \\
(22.4)\end{array}$ & $\begin{array}{c}78.8 \\
(22.4)\end{array}$ & $\begin{array}{r}76.9 \\
(20.6)\end{array}$ \\
\hline Premature death index (F) & $\begin{array}{c}38.7 \\
(10.4)\end{array}$ & $\begin{array}{c}37.2 \\
(8.8)\end{array}$ & $\begin{array}{c}34.5 \\
(9)\end{array}$ & $\begin{array}{c}34.9 \\
(8.3)\end{array}$ & $\begin{array}{c}33.6 \\
(7.1)\end{array}$ & $\begin{array}{l}33 \\
(7.1)\end{array}$ & $\begin{array}{r}31.4 \\
(6.5)\end{array}$ \\
\hline No. of local governments & 230 & 230 & 230 & 230 & 230 & 230 & 228 \\
\hline
\end{tabular}

Values are presented as mean (standard deviation).

$\mathrm{M}$, male; F, female.

'Unit: 1000000 Korean won.

${ }^{2}$ Standardized mortality per 100000 populations.

male standardized mortality rates and premature death indexes have decreased. The percentages of standardized mortality rates and the premature death index as variables in the males were higher than those of the females.

The correlation coefficients among major variables are shown in Table 2. The social expenditures per capita showed a positive correlation with the male standardized mortality rate and the male and the female premature death indexes. The local finance self-reliance ratio demonstrated a negative correlation with the standardized mortality rate and the premature death index in both males and females. The ratio of the local governments' self-managed social welfare projects and their self-financed coverage showed negative correlations with the female standardized mortality rate.

\section{The Association Between Social Expenditures} and the Age-standardized Mortality Rate

The associations between social expenditures and the agestandardized mortality rates by sex are summarized in Table 3 . The variable which showed a significant relationship with the standardized mortality rate in the same year was the expenditures for food and drug safety. An increase in expenditures by 100000 Korean won (approximately 100 US dollar) caused a decrease in the standardized rate of 70.8 among every 100000 people. Moreover, the expenditures for food and drug safety had a relationship with the female standardized mortality rate two years later (a decrease in the standardized mortality rate of 71.6 people for an increase in expenditures by 100000 Korean won). However, the result was not consistent because the 


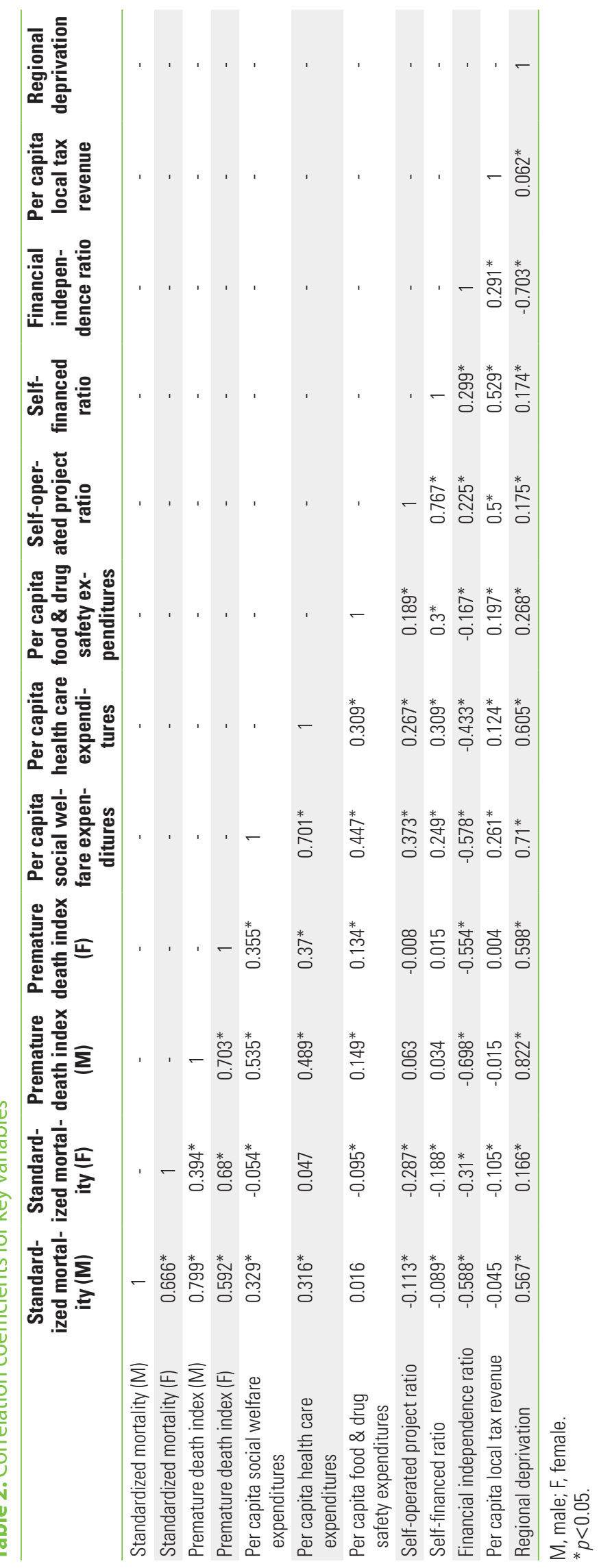

female standardized mortality rate in the same year showed a negative relationship, an increase in the standardized mortality rate of 34.6 per increase in expenditures by 100000 Korean won. The general social expenditures per capita had a relationship with a decrease in the female standardized mortality rate two years later (a decrease in the standardized mortality rate of 2.7 per increase of expenditures by 100000 Korean won).

The social expenditures per capita, the expenditures for health care, the share of social expenditures out of total expenditures, and the share of health care expenditures out of total expenditures showed no significant relationships with the standardized mortality rates in either sex.

\section{The Relationship Between the Social Expendi-} tures and the Premature Death Rate

The relationship between social expenditures and the premature death rate is summarized in Table 4. The social expenditures per capita showed a significant relationship with the premature death index for both males and females. This result was still consistent even when a lag effect with one to two years was applied. The premature death index was decreased by 0.5 to 1 in 1000 people with an increase in expenditures by 100000 Korean won. Like the relationship with the standardized mortality rate, the expenditures for food and drug safety had a relationship with decreases in the male premature death index in the same year and the female premature death index two years later; however, there was no relationship with the female premature death index in the same year.

The expenditures for health care per capita were associated with a reduction of the female premature death index one year later. The premature death index was decreased by 1.2 with the increase of expenditures by 100000 Korean won. The general social expenditures per capita were related with decreases in the male and the female premature death indexes in the same year and one and two years later. The premature death index decreased by 0.6 to 1.3 with an increase in expenditures by 100000 Korean won. The expenditures for educational welfare per capita showed a relationship with the premature death indexes for males in the same year and for males and females one year later. The premature death index was decreased by 0.8 to 1.1 with an increase in expenditures by 100000 Korean won.

There was no relationship between the share of health care expenditures as a proportion of the total expenditures and the premature death index; however, the share of social expendi- 
Table 3. Association between standardized mortality and social expenditures of local government, 2005 to 2010

\begin{tabular}{|c|c|c|c|c|c|c|}
\hline & \multicolumn{3}{|c|}{ Standardized mortality ${ }^{1}$ (male) } & \multicolumn{3}{|c|}{ Standardized mortality ${ }^{1}$ (female) } \\
\hline & Same year & 1-year time lag & 2-year time lag & Same year & 1-year time lag & 2-year time lag \\
\hline Total social expenditures ${ }^{2}$ & $\begin{array}{c}-0.001 \\
(-0.026,0.023 \\
[0.23])\end{array}$ & $\begin{array}{c}-0.013 \\
(-0.037,0.012 \\
[0.26])\end{array}$ & $\begin{array}{c}0.013 \\
(-0.017,0.042 \\
[0.44])\end{array}$ & $\begin{array}{c}-0.005 \\
(-0.018,0.009 \\
[0.39])\end{array}$ & $\begin{array}{c}-0.006 \\
(-0.019,0.008 \\
[0.35])\end{array}$ & $\begin{array}{c}-0.009 \\
(-0.025,0.007 \\
[0.27])\end{array}$ \\
\hline Health care expenditures ${ }^{2}$ & $\begin{array}{c}0.076 \\
(-0.017,0.168 \\
[0.28])\end{array}$ & $\begin{array}{c}-0.046 \\
(-0.136,0.045 \\
[0.29])\end{array}$ & $\begin{array}{c}-0.015 \\
(-0.111,0.08 \\
[0.41])\end{array}$ & $\begin{array}{c}-0.009 \\
(-0.06,0.042 \\
[0.39])\end{array}$ & $\begin{array}{c}-0.02 \\
(-0.07,0.03 \\
[0.36])\end{array}$ & $\begin{array}{c}0.001 \\
(-0.052,0.054 \\
[0.27])\end{array}$ \\
\hline $\begin{array}{l}\text { Food \& drug safety } \\
\text { expenditures }^{2}\end{array}$ & $\begin{array}{c}-0.708^{*} \\
(-1.294,-0.121 \\
[0.23])\end{array}$ & $\begin{array}{c}0.263 \\
(-0.335,0.861 \\
[0.33])\end{array}$ & $\begin{array}{c}-0.099 \\
(-0.74,0.543 \\
[0.41])\end{array}$ & $\begin{array}{c}0.346^{*} \\
(0.022,0.67 \\
[0.38])\end{array}$ & $\begin{array}{c}-0.359^{*} \\
(-0.69,-0.029 \\
[0.36])\end{array}$ & $\begin{array}{c}-0.716^{*} \\
(-1.069,-0.364 \\
[0.29])\end{array}$ \\
\hline $\begin{array}{l}\text { Sum of general social } \\
\text { expenditures }^{2}\end{array}$ & $\begin{array}{c}-0.008 \\
(-0.042,0.025 \\
[0.22])\end{array}$ & $\begin{array}{c}-0.007 \\
(-0.042,0.028 \\
[0.30])\end{array}$ & $\begin{array}{c}0.018 \\
(-0.026,0.062 \\
[0.44])\end{array}$ & $\begin{array}{c}-0.008 \\
(-0.026,0.01 \\
[0.38])\end{array}$ & $\begin{array}{c}-0.001 \\
(-0.02,0.019 \\
[0.36])\end{array}$ & $\begin{array}{c}-0.027^{*} \\
(-0.051,-0.002 \\
[0.26])\end{array}$ \\
\hline $\begin{array}{l}\text { Sum of educational } \\
\text { welfare expenditures }^{2}\end{array}$ & $\begin{array}{c}-0.013 \\
(-0.061,0.034 \\
[0.23])\end{array}$ & $\begin{array}{c}-0.028 \\
(-0.077,0.022 \\
[0.30])\end{array}$ & $\begin{array}{c}-0.005 \\
(-0.049,0.06 \\
[0.42])\end{array}$ & $\begin{array}{c}-0.008 \\
(-0.034,0.018 \\
[0.39])\end{array}$ & $\begin{array}{c}-0.012 \\
(-0.039,0.015 \\
[0.36])\end{array}$ & $\begin{array}{c}0.01 \\
(-0.02,0.04 \\
[0.27])\end{array}$ \\
\hline $\begin{array}{l}\text { Share of social } \\
\text { expenditures (\%) }\end{array}$ & $\begin{array}{c}0.556 \\
(-0.295,1.407 \\
[0.17])\end{array}$ & $\begin{array}{c}0.12 \\
(-0.734,0.974 \\
[0.31])\end{array}$ & $\begin{array}{c}-0.187 \\
(-1.186,0.812 \\
[0.42])\end{array}$ & $\begin{array}{c}0.396 \\
(-0.074,0.866 \\
[0.38])\end{array}$ & $\begin{array}{c}0.249 \\
(-0.223,0.721 \\
[0.35])\end{array}$ & $\begin{array}{c}0.421 \\
(-0.133,0.975 \\
[0.28])\end{array}$ \\
\hline $\begin{array}{l}\text { Share of health care } \\
\text { expenditures }(\%)\end{array}$ & $\begin{array}{c}1.454 \\
(-2.647,5.554 \\
[0.23])\end{array}$ & $\begin{array}{c}-2.077 \\
(-5.723,1.569 \\
[0.33])\end{array}$ & $\begin{array}{c}-1.114 \\
(-4.921,2.692 \\
[0.42])\end{array}$ & $\begin{array}{c}1.363 \\
(-0.902,3.627 \\
[0.38])\end{array}$ & $\begin{array}{c}-0.259 \\
(-2.277,1.8 \\
[0.36])\end{array}$ & $\begin{array}{c}0.795 \\
(-1.318,2.907 \\
[0.27])\end{array}$ \\
\hline $\begin{array}{l}\text { Share of food \& drug } \\
\text { safety expenditures (\%) }\end{array}$ & $\begin{array}{c}-16.752 \\
(-37.572,4.067 \\
[0.26])\end{array}$ & $\begin{array}{c}-1.764 \\
(-22.528,19.0 \\
[0.32])\end{array}$ & $\begin{array}{c}-15.278 \\
(-36.871,63.14 \\
[0.42])\end{array}$ & $\begin{array}{c}6.124 \\
(-5.385,17.633 \\
[0.38])\end{array}$ & $\begin{array}{c}-10.565 \\
(-22.039,0.909 \\
[0.37])\end{array}$ & $\begin{array}{c}-4.427 \\
(-16.422,7.567 \\
[0.27])\end{array}$ \\
\hline
\end{tabular}

Each column represents regression coefficient ${ }^{3}$ (95\% confidence interval $\left[R^{2}\right]$ ) of multiple regression, respectively.

'Unit: per 100000 populations.

${ }^{2} 1000$ Korean won per capita.

${ }^{3}$ Adjusted by year, national basic livelihood security beneficiaries per 1000 capita, divorce rate, local tax revenue per capita, region dummy (urban/rural). ${ }^{*} p<0.05$

tures and expenditures for food and drug safety among total expenditures were, rather, related to the increase in the premature death index.

\section{The Relationship Between the Voluntary Effort of the Local Government and the Mortality Level}

The result of the regression model with the ratio of the local government's self-managed social welfare projects and their self-financing as explanatory variables is shown in Table 5. The ratio of the local government's self-managed social welfare projects showed an association with the decline in the female standardized mortality rate. The standardized mortality rate was declined by 0.42 for each increase of one percentage point in expenditures for self-managed projects. However, there was no association with the premature death index. The ratio of the local government's self-financing had no relationship with the standardized mortality rates or the premature death indexes in either sex. This result is not presented in the table due to the limited data; however, considering the lag ef- fect of one to two years, the local government's voluntary effort had no relationship with the standardized mortality rate or the premature death index.

\section{DISCUSSION}

The standardized mortality rate and the premature death index varied significantly from year to year in every fixed effect regression model. The decline in the two dependent variables from year to year was mostly linear. This means that a period effect existed. However, the social expenditures per capita had a significant relationship with the premature death index even after adjustment for the period effect. Because of different definitions of variables, the composition of the regression model, and the time ranges, it is difficult to directly compare this study and previous studies from the US. However, unlike the US study in which the total standardized mortality rate by states decreased by 3.8 people in 100000 people with each increase in 100 US dollars of spending in the same year, the 
Table 4. Association between premature death index and social expenditures of local government, 2005 to 2010

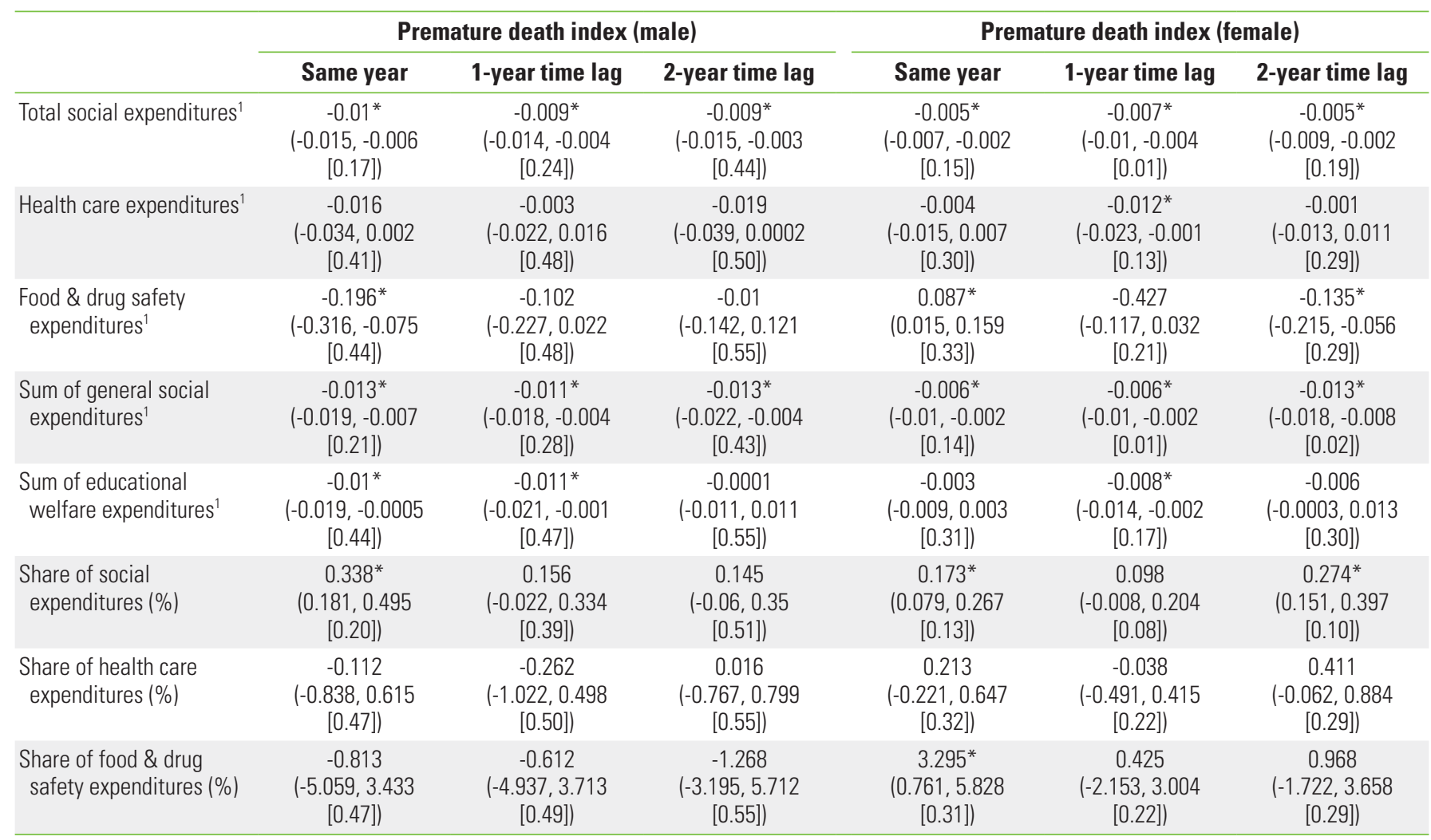

Each column represents a regression coefficient ${ }^{2}\left(95 \%\right.$ confidence interval $\left.\left[R^{2}\right]\right)$ of the multiple regression.

${ }^{1} 1000$ Korean won per capita.

${ }^{2}$ Adjusted by year, national basic livelihood security beneficiaries per 1000 capita, divorce rate, local tax revenue per capita, region dummy (urban/rural). ${ }^{*} p<0.05$.

Table 5. Association between standardized mortality/premature death index and voluntary effort of local government, 2007 to 2010

\begin{tabular}{|c|c|c|c|c|}
\hline & \multicolumn{2}{|c|}{ Standardized mortality ${ }^{1}$} & \multicolumn{2}{|c|}{ Premature death index } \\
\hline & Male & Female & Male & Female \\
\hline $\begin{array}{l}\text { Self-operated project ratio of local } \\
\text { government (\%) }\end{array}$ & $\begin{array}{c}0.323 \\
(-0.338,0.984[0.2])\end{array}$ & $\begin{array}{c}-0.424^{*} \\
(-0.787,-0.062[0.28])\end{array}$ & $\begin{array}{c}0.096 \\
(-0.036,0.229[0.52])\end{array}$ & $\begin{array}{c}-0.005 \\
(-0.076,0.086[0.30])\end{array}$ \\
\hline $\begin{array}{l}\text { Self-financed ratio of local } \\
\text { government }(\%)\end{array}$ & $\begin{array}{c}0.724 \\
(-0.008,1.455[0.15])\end{array}$ & $\begin{array}{c}0.288 \\
(-0.114,0.691[0.21])\end{array}$ & $\begin{array}{c}0.091 \\
(-0.056,0.238[0.52])\end{array}$ & $\begin{array}{c}0.0002 \\
(-0.089,0.09[0.30])\end{array}$ \\
\hline
\end{tabular}

Each column represents a regression coefficient ${ }^{2}\left(95 \%\right.$ confidence interval $\left.\left[R^{2}\right]\right)$ of the multiple regression.

1 Unit: per 100000 populations.

${ }^{2}$ Adjusted by year, national basic livelihood security beneficiaries per 1000 capita, divorce rate, local tax revenue per capita, region dummy (urban/rural). ${ }^{*} p<0.05$.

social expenditures per capita in the previous study were not related with the standardized mortality rate [12].

Expenditures for health care and for food and drug safety, which belong to the health and welfare budget category in the classification system of the Social Expenditure DB did not showed a consistent relationship with the decrease in the standardized mortality rate and the premature death index, which represent the mortality level. Expenditures for food and drug safety per capita showed a noticeable relationship with the standardized mortality rate (a decrease in the standardized mortality rate of 70 for each increase of one percentage point); however, expenditures for food and drug safety per capita showed a negative association with the female standardized mortality rate and the premature death index in the same year. One reasonable interpretation is that there are diverse variables like the relevance of health care policy, the effi- 
ciency and the effectiveness of services, and the exact delivery of services to those who need them during the process of actualizing the expenditures for health and welfare [19].

Another reason is that various social determinants affecting health status exist. The following results partly support this; the general social expenditures per capita had a significant relationship with the female standardized mortality rate even though there was no relationship between the social expenditures per capita and the health care expenditures per capita and the standardized mortality rate, while general social expenditures and expenditures for educational welfare were obviously associated with the premature death index. In a previous study on the effect of social expenditures by states on the suicide rate, unlike social expenditures, expenditures for health care had no statistical significance [15].

Unlike social expenditures per capita, expenditures for food and drug safety, general social expenditures, and expenditures for educational welfare, the voluntary effort of local governments did not show a significant association with the premature death index. This result could be explained (understood) by noting that public health-related demands with varying health status among local areas have not been considered in the planning, decision making, and implementation processes of local government policy [1]. However, the size, the level, and the approach of the voluntary efforts of local governments vary widely. Given this variation, if the dependent variables were established with different priorities such as the smoking rate or the harmful drinking rate in each local area, a meaningful result would be produced. Thus, careful attention is required to interpret the results. In addition, data on social expenditures analyzed in this study is limited in representing the efforts for social welfare by local governments because the social expenditures of local governments occupies only a portion of the total social expenditures that affect the local residents, and while the share of the total medical care budget is $4 \%$ to $6 \%$ in cities, counties, and provinces, there is no shared medical care budget in Seoul Metropolitan City or the autonomous regions of the metropolitan city [20].

It is also important not to overlook the direct application of the results of this study to policy. An increase in social expenditures per capita by 100000 Korean won was associated with a decrease in the premature death index by 0.5 to 1 per 1000 people. However, in reality, it is difficult to apply this result to the local level. In other words, it is not easy to determine whether the social expenditures of 10 billion Korean won (about 10 million US dollar) could prevent as much as 50 to 100 of potential loss of life. It has been shown that the social welfare variables relationship to the standardized mortality rate and the premature death index of local governments vary because the share of social expenditures out of the total expenditures does not have a relationship with the premature death index, and the expenditures for health care has only a limited effect. This means that lowering the mortality (i.e., increasing the age of mortality) through actual spending policy would be complex given the range of factors involved.

The limitations of this study are as follows: first of all, endogeneity was not fully taken into account. The local tax, which is an adjusted variable in the regression model, has a relationship with variables for social expenditures, and this endogeneity could cause a decrease in the explanatory power of the regression equation. However, an appropriate variable to be used as the instrumental variable could not be selected from the available data. Related to the first limitation, a second one is that diverse variables are insufficient. For a valid study design, taking into consideration diverse mortality levels, sufficient data to present the current status and characteristics of local governments is required. However, the currently available data at the city, county, and province levels is inadequate. For this reason, the presentation and understanding of relationships among variables are limited. In particular, it is known that variables for income and poverty of local areas are related to the mortality rate [21]. However, a number of variables related to local areas could not be included in this study. A regional deprivation index was considered as an adjusted variable; however, this index was excluded in the final model because it needed to be included as a time-invariant variable due to the lack of the data for every year, and this index itself showed a strong correlation with social expenditures.

The third limitation regards the consideration of the lag effect. During the study period, the standardized mortality rate and the premature death index varied significantly from year to year. To explain this result requires the assumption that socioeconomic and public health factors have influenced the increase in the age of mortality rather than that this result is a spontaneous event based on a spontaneous increase in the mortality level without interventions through specific policies. The relationship between the standardized mortality rate and the premature death rate on the one hand, and general social expenditures and expenditures for educational welfare, on the other, implies that there are various determinants for health. 
Moreover, social expenditure variables showed a relationship with the standardized mortality rate and premature death index. This result connotes that sufficient time is needed for the implementation of social expenditure budgets by practical policies and for their effects to appear. Because there must be other determinants for health that are not included in the regression equation of this study, the confusion would be partly alleviated if a more elaborate range of factors affecting the mortality level of local areas were included in the regression model.

This study was designed to examine the association between the social expenditures of local governments and the mortality level. Thus, the following results were confirmed. First, an association between social expenditures and the mortality level was identified. The social expenditures per capita showed a relationship to a decrease in the premature death index; however, there was no significant relationship with the standardized mortality rate. Second, the effects of variables for public health areas including health care, and food and drug safety were limited and did not show consistency. Third, the voluntary effort of local governments was related with a decrease in the female standardized mortality rate; however, there was no relationship with the premature death index.

\section{ACKNOWLEDGEMENTS}

This study is revised and expanded version of the manuscript presented at the 3rd Social Expenditure Database Conference by KIHASA on May 10, 2012.

\section{CONFLICT OF INTEREST}

The authors have no conflicts of interest with the material presented in this paper.

\section{REFERENCES}

1. Yoon TH. Regional differences in health and local government. Welf Trend 2010;139:51-54 (Korean).

2. Kim DS, Park HJ. Regional differntials in mortality in Korea, 1990-2000. Korea J Popul Stud 2003;26(1):1-30 (Korean).

3. Lee MS. Health inequalities among Korean adults: socioeconomic status and residential area differences. Korean J Sociol 2005;39(6):183-209 (Korean).

4. Yoon TH. Regional health inequalities in Korea: the status and policy tasks. J Crit Soc Welf 2010;30:49-77 (Korean).

5. Ko KH. Current situation of social expenditure and its policy implication. Health Welf Policy Forum 2007;131:21-34 (Korean).

6. Kim TI. Local autonomy and welfare expenditure of local government. Korean Public Adm Rev 2001;35(1):69-89 (Korean).

7. Choi J. Determinants of finance of local government and welfare expenditure. Korean Policy Sci Rev 2005;9(4):451-474 (Korean).

8. Lee JW, Kim KS. Determinants of the social welfare expenditure in local government: 1995-2005. Soc Welf Policy 2007;31: 105-124 (Korean).

9. Park Y, Kim MH, Kown S, Shin YJ. The association between public social expenditure and suicides: evidence from OECD countries. J Prev Med Public Health 2009;42(2):123-129 (Korean).

10. Cheong KS, Choi MH, Cho BM, Yoon TH, Kim CH, Kim YM, et al. Suicide rate differences by sex, age, and urbanicity, and related regional factors in Korea. J Prev Med Public Health 2012; 45(2):70-77.

11. Rajkumar AS, Swaroop V. Public spending and outcomes: does governance matter? J Dev Econ 2008;86(1):96-111.

12. Dunn JR, Burgess B, Ross NA. Income distribution, public services expenditures, and all cause mortality in US States. J Epidemiol Community Health 2005;59(9):768-774.

13. Kim AS, Jennings ET. Effects of U.S. States' social welfare systems on population health. Policy Stud J 2009;37(4):745-767.

14. Farahani M, Subramanian SV, Canning D. Effects of state-level public spending on health on the mortality probability in India. Health Econ 2010;19(11):1361-1376.

15. Minoiu C, Andres AR. The effect of public spending on suicide: evidence from U.S. state data. J Socio Econ 2008;37(1):237-261.

16. Min IS, Choi PS. STATA panel data analysis. Seoul: Jiphil Media; 2012, p. 2-3 (Korean).

17. Gardner JW, Sanborn JS. Years of potential life lost (YPLL): what does it measure? Epidemiology 1990;1(4):322-329.

18. Jang $\mathrm{DH}$. Dependent variable problems in comparative study of welfare expenditure of local government. Seoul: Korea Institute for Health and Social Affairs; 2012, p. 1-27 (Korean).

19. Filmer D, Pritchett $L$. The impact of public spending on health: does money matter? Soc Sci Med 1999;49(10):1309-1323.

20. Yoo WS. Regional differences in contributions of Medical Aid fund. Welf Trend 2011;157:24-29 (Korean).

21. Deaton A, Lubotsky D. Mortality, inequality and race in American cities and states. Soc Sci Med 2003;56(6):1139-1153. 